DOI 10.14746/ssp.2020.1.8

Krzysztof TOMASZEWSKI

Uniwersytet Warszawski

ORCID: 0000-0002-6324-1827

\title{
Rola czynnika ludzkiego w ksztaltowaniu polityki energetycznej współczesnego państwa
}

Streszczenie: Polityka energetyczna jest zaliczana do kategorii polityk gospodarczych. Ma jednak bardzo silny wpływ na funkcjonowanie całego społeczeństwa. Celem artykułu jest analiza, w jakim stopniu jest ona (lub może być) kształtowana pod wpływem czynnika ludzkiego i, jakie to ma znaczenie w kontekście jej planowania, implementacji oraz ewaluacji. Przedmiotem analizy są przede wszystkim te państwa (ugrupowania państw - Unia Europejska), gdzie występuje reżim demokratyczny i gospodarka wolnorynkowa. Są to - jak się wydaje - najbardziej sprzyjające warunki, aby społeczeństwo mogło efektywnie oddziaływać na kształt i funkcjonowanie sektora energetycznego. Zmierzeniem artykułu jest, aby poprzez analizę procesualną polityki energetycznej wskazać potencjalne (realne) możliwości udziału w niej czynnika ludzkiego.

Słowa kluczowe: gospodarka, energia, polityka energetyczna, opinia publiczna, społeczeństwo obywatelskie

\section{Wstęp}

Dolityka energetyczna zaliczana jest do kategorii polityk gospodarczych.

Jej realizacja ma służyć przede wszystkim zapewnieniu bezpieczeństwa gospodarczego państwa. Współcześnie trudno jednak wyobrazić sobie kształtowanie tej polityki bez uwzględnienia jej wpływu na społeczeństwo. Od kilkunastu lat jest ona coraz bardziej kojarzona z problematyką zrównoważonego rozwoju i ochroną środowiska naturalnego. W Unii Europejskiej określa się ją najczęściej mianem polityki energetyczno-klimatycznej, dla podkreślenia szerszego kontekstu, aniżeli tylko wymiar ekonomiczny.

Społeczeństwo może odbierać politykę energetyczną na wiele sposobów: jako działania państwa na rzecz zapewnienia stałych dostaw surowców energetycznych, jako podejmowanie nowych inwestycji energetycznych (np. budowa infrastruktury energetycznej), jako działania na rzecz ochrony środowiska naturalnego (np. walka ze smogiem), czy działania na rzecz poprawy efektywności energetycznej. 
Celem niniejszego artykułu jest przybliżenie problematyki oddziaływania społecznego na procesy kształtowania polityki energetycznej, bezpieczeństwa energetycznego i sensu largo: sektora energetycznego. Analiza ta zostanie zaprezentowana zarówno w wymiarze krajowym, jak również międzynarodowym. Polityka energetyczna dawno już przestała być domeną pojedynczego rządu. Poprzez procesy globalizacji oraz międzynarodowej integracji gospodarczej i politycznej została ona przeniesiona na poziom ponadnarodowy i stała się przedmiotem współdziałania państw w stosunkach zagranicznych. Można uznać, iż jest ona częścią ponadnarodowej debaty, prowadzonej zarówno regionalnie (np. na forum Unii Europejskiej), jak i globalnie (np. w ramach Organizacji Narodów Zjednoczonych - tzw. konferencje COP) (Szczerbowski, Ceran, 2017, s. 17-28).

Hipoteza artykułu brzmi: w systemie demokratycznym o gospodarce rynkowej czynnik społeczny pełni ważną rolę, oddziałującą na kształt polityki energetycznej i funkcjonowanie sektora energetycznego.

$\mathrm{Z}$ perspektywy teoretycznej wykorzystana zostanie metoda analizy systemowej z elementami ujęcia decyzyjnego. Posłuży to do zbadania mechanizmów systemu politycznego, zarówno w wymiarze ponadnarodowym (w Unii Europejskiej), jak i narodowym (na przykładach wybranych państw) oraz jego reakcji na zachowania społeczne w kontekście inwestycji w sektorze energetycznym. Istotne jest ustalenie, czy i w jaki sposób społeczeństwo oddziałuje na politykę energetyczną współczesnego państwa ${ }^{1}$.

\section{Oddziaływanie społeczne na politykę energetyczną}

Wymienione w powyższych akapitach płaszczyzny badania wpływu czynnika społecznego na politykę energetyczną odnosiły się - w szczególności - do wymiaru przedmiotowego. Tymczasem, dla zrozumienia

${ }^{1}$ Inspiracją dla przygotowania niniejszego tekstu są prace badawcze, które uwzględniają problematykę ekonomiczną w kontekście uwarunkowań społecznych, zarówno autorów zagranicznych, m.in. A. Florini i B. K. Sovacool (2009); C. Schively (2007); M. Schneider (2010); J. Knox-Hayes, M. A. Brown, B. K. Sovacool, Y. Wang (2013) Ch. Von Hirschhausen (2014), D. Nikhil (2018); I. Campos, E. Marín-González, G. Luz, J. Barroso, N. Oliveira (2019), jak również przedstawicieli polskiej nauki, m.in. A. Strupczewski (2009); Z. Łucki i A. Misiak (2010); S. Mrozowska (2016); P. Stankiewicz (2016); A. Wagner (2016); J. Gryz, A. Podraza i M. Ruszel (2018). 
problematyki wpływu społecznego na politykę energetyczną, kluczowe znaczenie ma również analiza procesualna. Na potrzeby niniejszego artykułu będzie ona rozumiana, jako oddziaływanie społeczne na kwestie energetyczne w różnych fazach polityki energetycznej: od jej projektowania, poprzez implementację aż do ewaluacji jej skutków (zob. wykres 1).

\section{Wykres 1. Analiza procesualna polityki energetycznej}

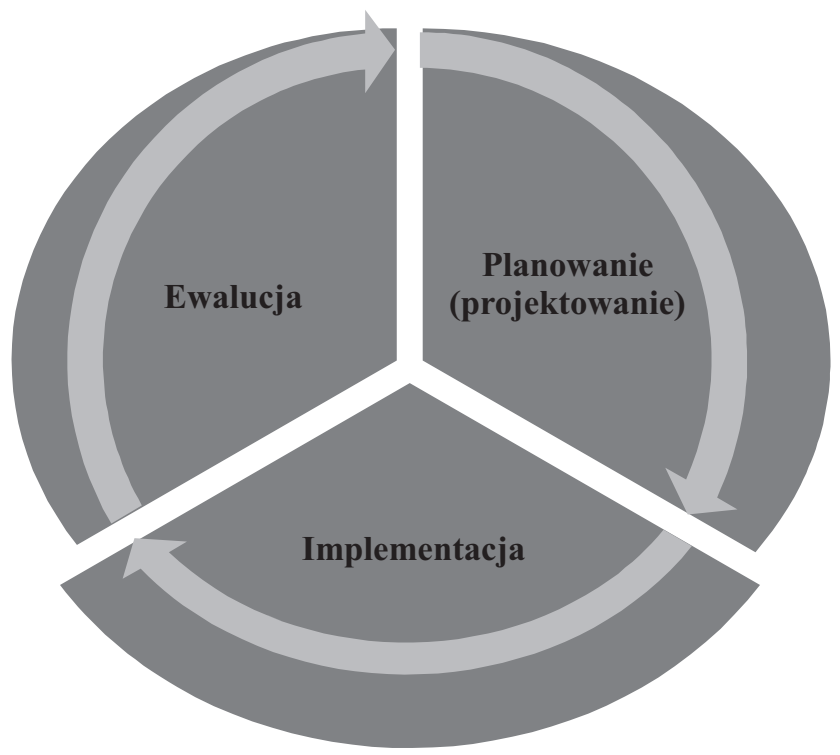

Źródło: Opracowanie własne.

Etap pierwszy: projektowanie polityki energetycznej oznacza de facto opracowanie strategii rozwoju sektora energetycznego oraz wizji jego rozwoju w kolejnych dziesięcioleciach (Florini, Sovacool, 2009, s. 5239-5248). Tworzenie takiej strategii najczęściej stanowi efekt działań rządu, poprzedzonych budowaniem konsensusu politycznego między różnymi siłami partyjnymi. Trudno bowiem wyobrazić sobie przygotowanie strategii przez zwycięską partię (lub koalicję), która po kolejnych wyborach nie uzyska wsparcia elektoratu, a opracowana w ten sposób strategia zostanie podważona przez następców. Takie działanie spowodowałoby nie tylko rozchwianie gospodarki, czy swoisty chaos w realizowaniu przedsięwzięć inwestycyjnych, ale również - z politycznego punktu widzenia - byłoby nieuzasadnione. 
Budowanie strategii politycznej w oparciu o konsensus polityczny stanowi jeden $\mathrm{z}$ etapów na drodze do realizacji polityki energetycznej. Nie mniej ważnym działaniem wydaje się - w tym kontekście - prowadzenie konsultacji ze strategicznymi przedsiębiorstwami sektora energetycznego, jak również realizowanie konsultacji społecznych.

Konsultowanie pomysłów dotyczących sektora energii z firmami sektora energetycznego wydaje się dość oczywiste. Od kondycji i możliwości przedsiębiorstw energetycznych zależą bowiem w dużej mierze realne możliwości wprowadzenia w praktyce ambitnych strategii przyjmowanych przez elity rządzące (por. Bosch, Schwarz, 2019, s. 1621).

Można byłoby wręcz zaryzykować stwierdzenie, że to właśnie firmy energetyczne - przy wsparciu rządu - najczęściej realizują strategię w zakresie polityki energetycznej. Bez względu bowiem na charakter rynku energii: poziom jego zorganizowania i rozdrobnienia, zarówno znaczące, duże firmy (tzw. SOE - State Owned Enterprises), jak również mniejsze podmioty są bardziej lub mniej związane zapisami zawartymi w rządowych strategiach energetycznych (np. w kwestiach dotyczących pozyskiwania surowców energetycznych, dywersyfikacji dróg i kierunków dostaw), albo po prostu podlegają regulacjom prawnym, które stanowią najczęściej emanację rozwiązań przyjętych w dokumentach strategicznych (por. Schneider, 2008, s. 6-7).

W zależności od charakteru przyjętych w danym państwie rozwiązań prawnych, konsultacje sektorowe mogą być zróżnicowane co do przedmiotu konsultacji, jak również zakresu firm, które są przez rządzących konsultowane (Ribeiro, Ferreira, Araújo, 2011, s. 4361-4369). Im szersze konsultacje, tym większa szansa na zrozumienie tzw. branży i jej wsparcie przy realizacji określonych działań. W konsekwencji ma to wpływ na sposób realizacji polityki energetycznej państwa, a w dłuższej perspektywie na funkcjonowanie całej gospodarki państwa (Stankiewicz, 2016, s. 235-236).

Reasumując udział podmiotów gospodarczych w procesie projektowania polityki energetycznej wydaje się kluczowy i niezbędny. Ma to istotny wpływ na sposób realizacji założeń tej polityki, a w kontekście zakładanych celów, pozwala zwiększyć szanse na pozytywny bilans przy dokonywaniu ewaluacji ex post tej polityki.

Osobną kwestią pozostaje problem włączenia do polityki energetycznej obywateli, czy de facto określenie roli czynnika społecznego (Hausner, 2010, s. 9-14). Odnosząc się do wskazanych powyżej trzech etapów: planowania - realizacji - ewaluacji polityki energetycznej, na 
każdym z nich można znaleźć i wyróżnić inne problemy oraz wyzwania związane z czynnikiem społecznym.

Etap planowania, czyli tworzenia strategii oznacza poszukiwanie odpowiednich rozwiązań, kierunków działania, które w przyszłości okażą się korzystne nie tylko dla państwa - jego gospodarki oraz bezpieczeństwa energetycznego, dla firm sektora energetycznego, ale również dla obywateli. Na tym etapie warto byłoby wskazać przede wszystkim trzy możliwości włączenia obywateli w proces tworzenia polityki energetycznej:

- referendum - czyli powszechne głosowanie w sytuacjach o szczególnym znaczeniu dla całej populacji danego państwa. Taka formuła mogłaby być korzystna zwłaszcza w takich sprawach, gdzie antycypowane są szczególne trudności przy dokonywaniu transformacji gospodarczej (np. budowa nowej elektrowni jądrowej w danym państwie). Przeprowadzenie w tym zakresie odpowiedniej kampanii informacyjnej, działanie na rzecz niwelowania tzw. mitów oraz wskazanie potencjalnych korzyści dla obywateli mogłoby spowodować, iż wprowadzanie energetyki jądrowej przebiegałoby w sposób znacznie bardziej spójny, niż miało to miejsce w dotychczasowych przypadkach stosowania tego rodzaju technologii (np. we Francji) (por. Schneider, 2010, s. 197-199).

Oczywiście, biorąc pod uwagę możliwość głosowania powszechnego (w referendum), należy zawsze dokonać analizy potencjalnych skutków: frekwencja oraz możliwe rozstrzygnięcia (np. referendum wiążące na „tak”, referendum wiążące na „nie”, referendum niewiążące z przewagą głosów na „tak”, referendum niewiążące z przewagą głosów na „nie”). Rozstrzygnięcia tego rodzaju mogą być niekiedy niekorzystne dla rządzących, gdyż nie pozwolą zrealizować w pełni - zakładanych w czasie kampanii wyborczej - planów strategicznych. Innym razem jednak mogą dawać silną legitymizację do podejmowania określonych przedsięwzięć inwestycyjnych, które uzyskały poparcie społeczne (por. Strupczewski, 2009, s. 2).

- sondaż opinii publicznej - może stanowić dogodny instrument dla systematycznej weryfikacji nastawienia społeczeństwa zarówno na poziomie ogólnych strategii (pojedynczego państwa, czy całej Unii Europejskiej), ale również na poziomie regionalnym czy lokalnym, gdzie należałoby ocenić potencjalny odbiór społeczny nowych planów inwestora, czy inicjatyw podejmowanych przez władze samorządowe (por. Rychlicki, Kossowski i in., 2016, s. 136). Sondaż, przy 
stosunkowo niskich kosztach, pozwala zweryfikować nie tylko zakres wiedzy obywateli, ale również ocenić ich postawy, a tym samym antycypować emocje (pozytywne lub negatywne), jakie będą towarzyszyły określonym przedsięwzięciom. Dobrym przykładem w tym zakresie są przeprowadzane przez UE sondaże opinii publicznej (zob. wykres 2), które stanowią swoisty barometr nastrojów Europejczyków względem nowych inicjatyw podejmowanych na poziomie ponadnarodowym.

Wykres 2. Wspólna polityka energetyczna Unii Europejskiej (procentowo)

Czy popiera Pan(i) prowadzenie wspólnej europejskiej polityki energetycznej?

$\begin{array}{lllllllllllllllllllllllllllll}4 & 10 & 7 & 10 & 8 & 2 & 9 & 8 & 4 & 4 & 6 & 5 & 4 & 7 & 14 & 10 & 12 & 9 & 13 & 14 & 10 & 10 & 8 & 10 & 12 & 4 & 20 & 21 & 8\end{array}$

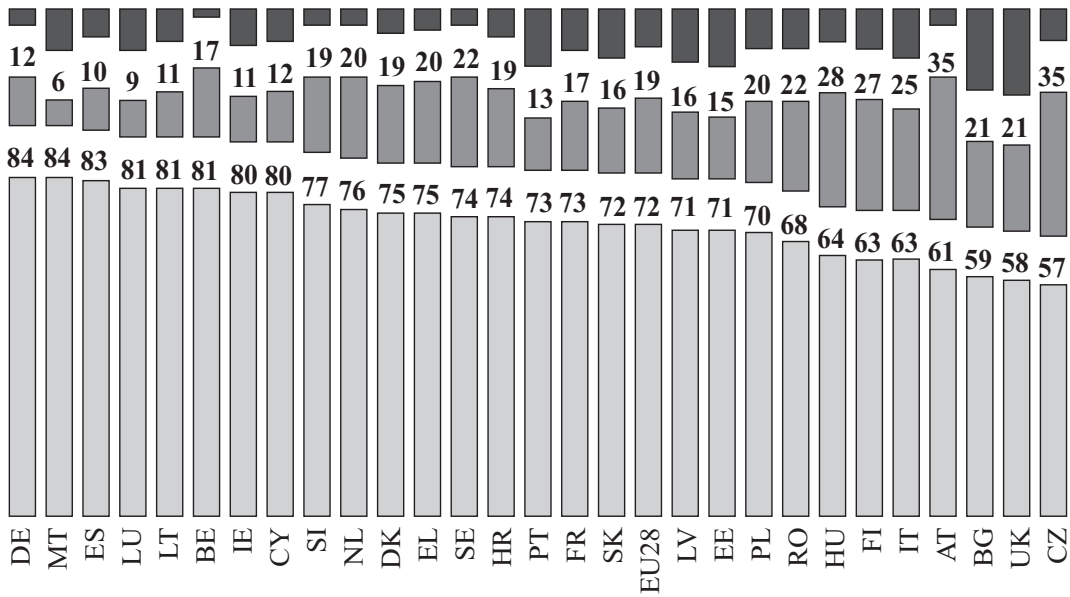

$\square$ Nie wiem $\quad \square$ Nie $\quad \square$ Tak

Źródlo: Standardowy Eurobarometr, Poglady Europejczyków na temat priorytetów Unii Europejskiej, nr 87 (maj 2017).

- wybory - partie polityczne mogłyby już na etapie kampanii wyborczej formułować swoje jasne stanowisko w odniesieniu do własnej wizji polityki energetycznej i sektora energii. Pozwoliłoby to obywatelom dokonywać właściwych wyborów w zależności od orientacji politycznej (np. proekologiczna orientacja obywateli skutkowałaby poparciem dla ugrupowań głoszących program w zakresie zrównoważonego rozwoju, ochrony środowiska, wdrażania odnawialnych źródeł energii, zmniejszania emisji $\mathrm{CO}_{2}$ do atmosfery). Tymczasem rzadko zdarza się, iż partie polityczne prezentują spójny program w zakresie polityki ener- 
getycznej. Jest ona najczęściej traktowana jako element polityki gospodarczej danego ugrupowania (Bezpieczeństwo energetyczne..., 2015).

- konsultacje społeczne - jest sprawą oczywistą, iż wszystkie problemy energetyczne nie mogą być zasygnalizowane obywatelom w czasie kampanii wyborczej do parlamentów, czy też nie mogą podlegać procesowi referendalnemu (choćby ze względu na wysokie koszty tego typu rozstrzygnięć, jak również nieprzewidywalny wynik frekwencji). Dlatego skutecznym rozwiązaniem w tym zakresie wydaje się mechanizm konsultacji społecznych (np. w Polsce - konsultacje społeczne w sprawie wprowadzenia tzw. klastrów energii) (Ministerstwo Energii, 2017). Tego rodzaju rozwiązania $\mathrm{z}$ powodzeniem wprowadzane są nie tylko na poziomie narodowym, ale również ponadnarodowym. Dobrym przykładem jest Unia Europejska, która poprzez publikowanie tzw. zielonych ksiąg (ang. green paper), proceduje nad zmianami strategii i nowymi rozstrzygnięciami w dziedzinie polityki i gospodarki. Obywatele mają szansę wypowiedzieć swoje zdanie, zarówno w formie sformalizowanej (poprzez stowarzyszenia czy organizacje pozarządowe), jak również indywidualnie (głosy ekspertów, naukowców itp.) (zob. Tomaszewski, 2017, s. 78-101).

Podsumowując, rola czynnika społecznego na etapie planowania strategii dla sektora energetycznego wydaje się bardzo istotna (Szustek, 2009, s. 17). Po pierwsze - może wzmacniać legitymizację dla nowych działań, których celem jest projektowanie zmiany gospodarczej (np. wprowadzenie energetyki atomowej do bilansu energetycznego danego państwa). Po drugie - poprawia poziom świadomości obywateli, którzy uczestnicząc w projektowaniu polityki bardziej efektywnie i z zaangażowaniem uczestniczą w jej wdrażaniu (np. obywatele Niemiec, choć płacą wyższe rachunki za energię, a część populacji zatrudniona $\mathrm{w}$ tradycyjnym przemyśle energetycznym straciła pracę, nie kontestują programu Energiewende i wdrażania odnawialnych źródeł energii na szeroką skalę) (Von Hirschhausen, 2014, s. 1-12). Po trzecie - wzrost zaangażowania obywateli w problematykę sektora energetycznego może skutkować pozytywnie w odniesieniu do podnoszenia poziomu bezpieczeństwa energetycznego państwa. Obywatele wrażliwi na kwestie sektora energetycznego z większym zrozumieniem będą akceptowali działania rządu i firm energetycznych zmierzające do zmian w bilansie energetycznym, stabilizacji cen energii, czy dywersyfikacji dróg i kierunków dostaw surowców energetycznych. 
Przechodząc do etapu drugiego: implementacji polityki energetycznej w kontekście zaangażowania obywateli, należałoby wskazać następujące wyzwania:

- kampanie informacyjne - na rzecz podnoszenia świadomości obywateli w zakresie aktualnej strategii energetycznej, czy planowanych zmian. Korzystna wydaje się sytuacja, w której obywatele mają świadomość takich problemów jak: efektywność energetyczna, bezpieczeństwo energetyczne, dywersyfikacja dróg i kierunków dostaw surowców energetycznych, bilans energetyczny, albo przynajmniej rozumieją, w jakim stopniu ceny energii są warunkowane kosztami jej produkcji, lub w jakiej mierze ceny paliw na stacjach benzynowych stanowią odzwierciedlenie sytuacji na rynkach międzynarodowych. Taki efekt można osiągnąć poprzez wprowadzanie do debaty publicznej problemów energetycznych i wydobywanie ich z ,getta" specjalizacji zrozumiałej jedynie dla ekspertów (Wagner, 2016, s. 15-23). Tego rodzaju wiedza winna być pokazywana jako obszar istotny dla zwykłego obywatela i jego ekonomicznej codzienności (korelacja ww. problemów z płatnościami rachunków za gaz, ciepło, energię elektryczną, czy paliwo na stacjach benzynowych; brak przerw w dopływie energii do mieszkań);

- konsultacje społeczne - stanowią ważny element zarówno na etapie planowania polityki energetycznej, jak również jej realizacji. Znane i opisywane $\mathrm{w}$ literaturze problemy $\mathrm{z}$ wdrażaniem nowych inwestycji zostały określone jako tzw. syndrom NIMBY, czasem również jako syndrom BANANA (Łucki, Misiak, 2010, s. 221-223). Tego rodzaju określenia nawiązują do niezadowolenia społecznego względem nowych przedsięwzięć w sektorze energetycznym (np. budowa nowych elektrowni wiatrowych, budowa spalarni odpadów, czy budowa elektrowni jądrowych), które niejednokrotnie prowadzą do faktycznego zablokowania projektu (zob. Frączek, 2011, s. 65-78). W takich sytuacjach jedynym skutecznym remedium wydaje się nawiązanie dialogu między interesariuszami (np. samorządem, inwestorem, społecznością regionalną czy lokalną). Nawiązanie dialogu, omówienie problematyki CSR (ang. corporate social responsibility), zaprezentowanie uwarunkowań związanych z nową inwestycją mogą stanowić ważny krok na drodze do zdobywania zaufania lokalnej społeczności, która obawiając się o swoje zdrowie, bezpieczeństwo, mienie, czy utratę wartości rezydualnej nieruchomości jest gotowa zablokować wszelkie działania inwestora (Szot-Gabryś, 2013; Gołaszewska-Kaczan, 2009; Komisja Europejska, 2001); 
- rzetelna informacja - nieufność społeczeństwa wobec nowych inwestycji, czy obawa wobec niektórych technologii produkcji energii (np. energii jądrowej) może być uwarunkowana poczuciem braku rzetelnej informacji ze strony władz, czy podmiotów odpowiedzialnych w sytuacjach zagrożenia (por. Stankiewicz, Stasik, Suchomska, 2015, s. 67-72; Strupczewski, 2009, s. 4). Jest to szczególnie widoczne na przykładzie energetyki jądrowej (zob. wykres 3).

Wykres 3. Budowa elektrowni jądrowych - zwolennicy i przeciwnicy (w \%)

Gdyby poproszono Pana(ia) o zajęcie jednoznacznego stanowiska w sprawie budowy takich elektrowni w naszym kraju, to czy byl(a)by Pan(i) za

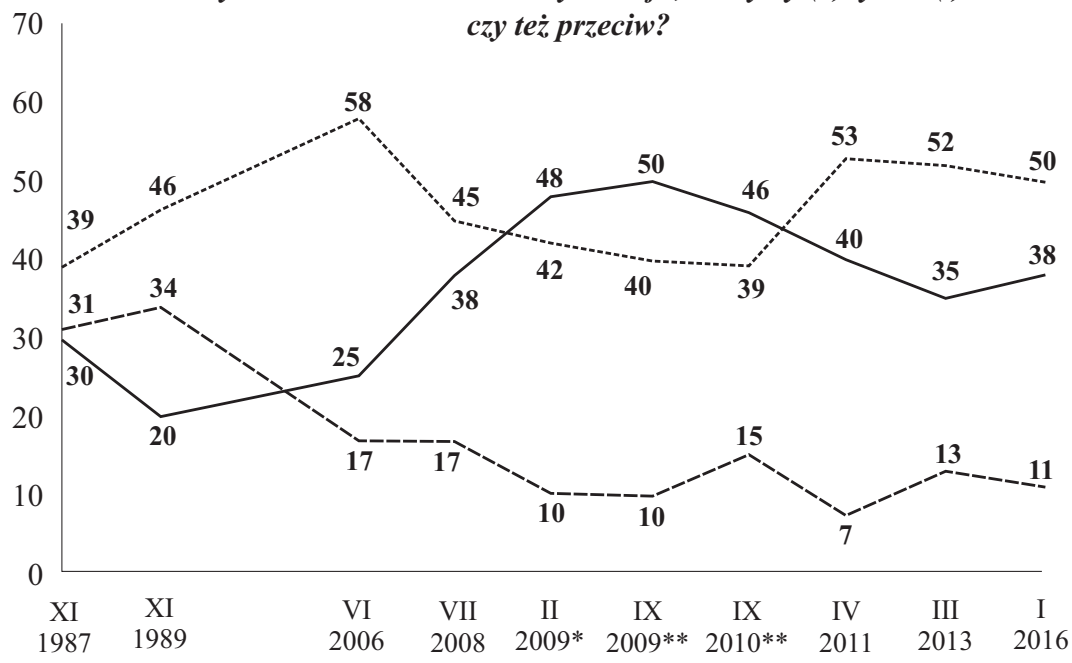

— Opowiadał(a)bym się za budową Sprzeciwiał(a)bym się budowie

---- Nie potrafię zająć stanowiska $\mathrm{w}$ tej sprawie***

* Badanie dla Ambasady Brytyjskiej.

** Badanie dla Ministerstwa Gospodarki.

*** W latach 2009-2011 i 2016 odpowiedź brzmiała „trudno powiedzieć”.

Źródlo: CBOS, Opinie i diagnozy, nr 34/2016, Polacy o źródlach energii, polityce energetycznej i ochronie środowiska, red. M. Gwiazda, P. Ruszkowski, Warszawa, s. 14.

Choć jest to technologia z powodzeniem wykorzystywana na świecie od lat 50. XX wieku, a poważne zdarzenia związane z awariami miały miejsce zaledwie trzykrotnie (Three Mile Island - USA, Czarnobyl - Ukraina d. ZSRR, Fukushima - Japonia), to jednak panuje społeczna 
obawa, że produkcja tego rodzaju energii obarczona jest bardzo wysokim ryzykiem (Młynarski, 2018, s. 85). Jest to związane m.in. z niedostateczną informacją, jaka w sytuacjach kryzysowych dostarczana była społeczeństwu (Deb, 2018, s. 474-475). Utrwaliło się w ten sposób przekonanie, iż w takich momentach podmioty odpowiedzialne nie przekazują rzetelnych i wiarygodnych danych na temat zdarzenia, aby uniknąć konsekwencji oraz zapobiec potencjalnym atakom paniki. To przyczynia się do narastania stereotypów i warunkowanych nimi lęków wobec tego, co nieznane i niezrozumiałe (Pachocki, 2006; Stankiewicz, 2016, s. 221; Mielczarski, 2009, s. 4).

Podsumowując, drugi etap działania w zakresie polityki energetycznej - czyli implementacja, należałoby podkreślić przede wszystkim dwie kwestie. Po pierwsze - potrzeba prezentowania społeczeństwu rzetelnej informacji, która pozwoli uwolnić umysły od myślenia stereotypowego i pozwoli dostrzec korzyści z realizacji nowych projektów energetycznych i wdrażania nowoczesnych technologii (Rychlicki, Kosowski i in., 2016, s. 143-144). Pozwoli to zniwelować tzw. lęk przed nieznanym. Po drugie - potrzeba podmiotowego traktowania. Społeczeństwo, które jest partnerem dialogu społecznego ma poczucie wpływu, oddziaływania na otoczenie, a dzięki temu bardziej utożsamia się z nowymi inicjatywami, w sprawie których odbywały się konsultacje, można było się wypowiedzieć (Szustek, 2009, s. 17-35).

Trzeci etap: ewaluacja polityki energetycznej, ma miejsce jak się wydaje przy urnach wyborczych i dokonuje się $\mathrm{w}$ akcie politycznego wyboru, którego mogą dokonać obywatele przy okazji procedur skrutacyjnych. Poparcie określonych rozwiązań będzie skutkowało wyborem tej formacji politycznej, której działania odpowiadają bieżącym potrzebom obywateli i stanowią odpowiedź na ich oczekiwania, np. poprzez zapewnienie stabilnych cen energii, zapewnienie niezakłóconych dostaw paliw i energii na rynek (po cenach akceptowalnych społecznie), czy wreszcie - odpowiednie zdywersyfikowanie bilansu energetycznego państwa.

Konkludując, trudno współcześnie wyobrazić sobie planowanie, implementację, czy ewaluację polityki energetycznej współczesnego państwa demokratycznego o gospodarce rynkowej bez udziału czynnika społecznego (Łucki, Misiak, 2010, s. 110). Można oczywiście podjąć dyskusję na temat zakresu tego oddziaływania. Będzie on z pewnością różny w różnych państwach, w zależności od przyjętych rozwiązań prawnych na poziomie konstytucji, czy ustaw zwykłych. Nawet organizacje międzynarodowe, takie jak Unia Europejska, dostrzegają taką potrzebę. Stąd coraz szersze stosowanie konsultacji społecznych przy projektowa- 
niu i wprowadzaniu nowych rozwiązań politycznych na poziomie wspólnotowym (por. Komisja Europejska, 2010, 2015, 2017).

\section{Dlaczego warto uwzględniać czynnik społeczny w polityce energetycznej?}

W analizie dotyczącej polskiego sektora energii firma Deloitte (2016) wskazała na zjawisko kształtowania się w ostatnich latach tzw. mega trendów energetycznych, czyli pewnych prawidłowości zachodzących w politykach energetycznych i sektorach energii współczesnych państw. Jednym z takich zjawisk wskazywanych we wspomnianej analizie jest rosnąca świadomość ekologiczna i partycypacja społeczna. Zainteresowanie obywateli kwestiami środowiskowymi sprawia, że inwestycje energetyczne oceniane są w perspektywie ich oddziaływania na otoczenie. Społeczeństwo ma świadomość (zob. wykres 4), iż produkcja energii

\section{Wykres 4. Świadomość problemów ochrony środowiska}

Czy, Pana(i) zdaniem, ocieplenie klimatu, emisja dwutlenku wegla do atmosfery oraz zwiąane z tym zagrożenia środowiska naturalnego to:

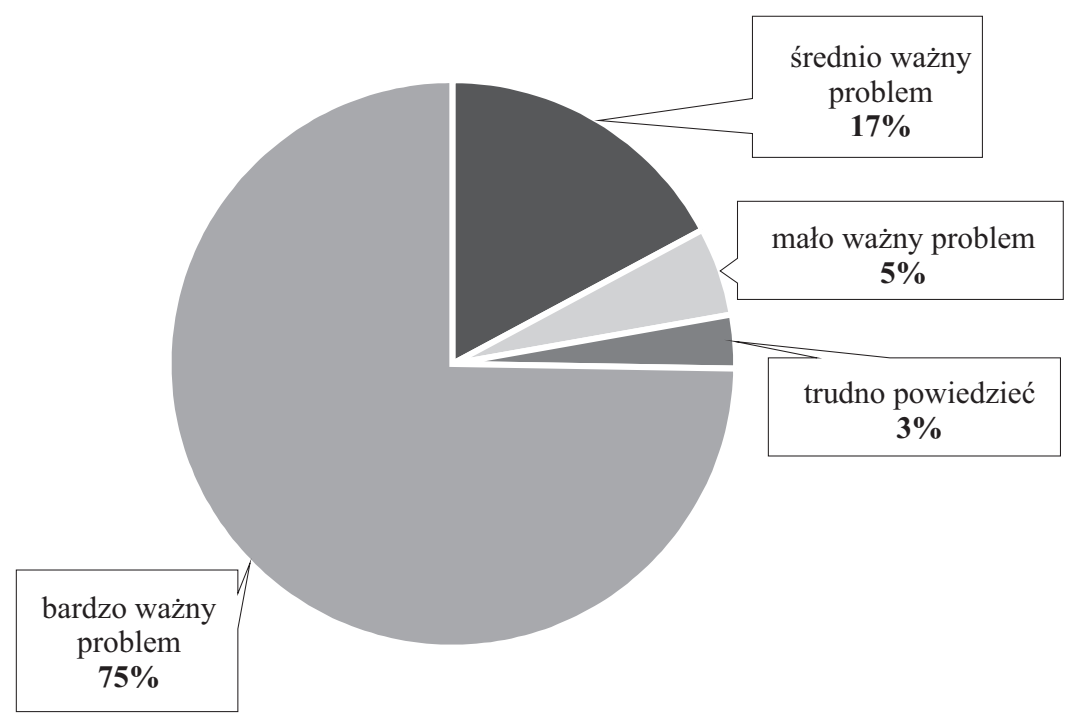

Źródło: CBOS, Opinie i diagnozy, nr 34/2016, Polacy o źródlach energii, polityce energetycznej i ochronie środowiska, red. M. Gwiazda, P. Ruszkowski, Warszawa, s. 16. 
może w znacznym stopniu obciążać środowisko naturalne, jak również wpływać na poziom ich bezpieczeństwa, stąd nieprzychylne niejednokrotnie postawy wobec energetyki jądrowej, energetyki konwencjonalnej (np. budowa odkrywkowych kopalni węgla brunatnego), czy niechęć wobec energetyki wiatrowej (np. kiedy farmy wiatrowe lokalizowane są zbyt blisko siedzib ludzkich) (por. Mielczarski, 2009, s. 4).

Udział obywateli w podejmowaniu decyzji w odniesieniu do kwestii środowiska, a pośrednio również energii należy rozumieć nie tylko w kategoriach postulatu. Jest on gwarantowany poprzez istniejące dokumenty o charakterze legislacyjnym zarówno na poziomie międzynarodowym (np. konwencja z Aarhus, 1998, prawo UE), jak również na poziomie krajowym (np. w Polsce - procedury oceny oddziaływania na środowisko). Oznacza to, że brak uwzględnienia głosu społecznego w planowaniu nowej inwestycji może skutkować jej opóźnieniem, a nawet zablokowaniem (w przypadku silnego oporu ze strony dobrze zorganizowanej społeczności) (por. Knox-Hayes, Brown i in., 2013, s. 609-622).

Myśląc o znaczeniu czynnika społecznego w polityce energetycznej, należałoby uwzględnić kilka perspektyw analitycznych, które wynikają z odmiennych, aczkolwiek przenikających się ról, w jakich znajduje się przeciętny, indywidualny uczestnik rynku energii:

- obywatel - jest odbiorcą energii elektrycznej i cieplnej oraz korzysta z paliw (np. diesel, benzyna, gaz ziemny, olej opałowy) niezbędnych do przemieszczania się, czy ogrzewania mieszkań. Ma świadomość swoich praw oraz potrzeb. Oczekuje on od dostawców produktów innowacyjnych, wytwarzanych w oparciu o najnowsze technologie, jednocześnie z poszanowaniem środowiska naturalnego i po akceptowalnych cenach (zobacz wykres 5). Powszechna dostępność portali społecznościowych, zaangażowanie w problematykę ochrony środowiska, moda na życie „eko” powoduje, że w skrajnych przypadkach obywatele-konsumenci mogą podejmować zorganizowane akcje w ramach tzw. syndromu NIMBY, które de facto wpływają na los inwestycji energetycznych.

- prosument - słowo hybryda, która zawiera w sobie: ,producenta” i ,konsumenta”. Wzrost popularności nowych technologii wytwarzania energii (zwłaszcza OZE) powoduje, iż wielu obywateli (np. w Niemczech) z powodzeniem łączy rolę odbiorcy energii z rolą jej producenta (Knopf, Schmid, Pechan, 2016, s. 263-275). Wytwarzanie energii staje się procesem demokratycznym, dostępnym dla każdego, kto jest nim zainteresowany i dysponuje środkami finansowymi na 
Wykres 5. Priorytety unii energetycznej - oceny społeczne (raport: Polska)

Które z następujących celów powinny stanowić Pana(i) zdaniem priorytet europejskiej unii energetycznej?

zagwarantowanie rozsądnych cen energii dla konsumentów

rozwijanie energii ze źródeł odnawialnych ochrona środowiska naturalnego

zmniejszenie zużycia energii

zagwarantowanie nieprzerwanych dostaw energii zagwarantowanie niezależnosci UE w dziedzinie energii

walka z globalnym ociepleniem zagwarantowanie rozsądnych cen energii dla przedsiębiorstw zagwarantowanie konkurencyjności przemysłu UE

wykorzystanie zbiorowego potencjału UE w negocjacjach $\mathrm{z}$ dostawcami energii

połączenie insfrastuktury państw członkowskich UE

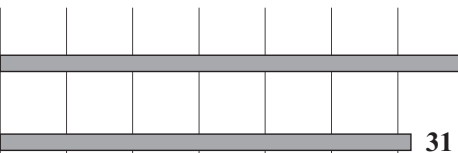

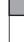
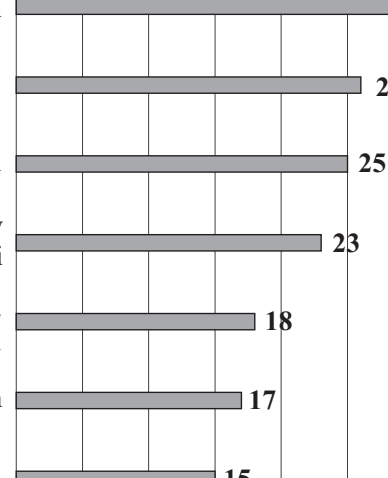

15

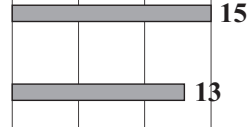

5

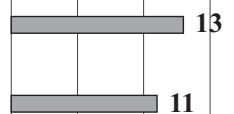

trudno powiedzieć

żadne

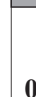

$\mathbf{0}$

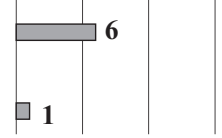

$\mathrm{N}=1033$

Źródło: Standardowy Eurobarometr, Opinia publiczna w Unii Europejskiej - raport krajowy: Polska, nr 82, jesień 2014, s. 9.

rozpoczęcie tego rodzaju działalności gospodarczej. Jest to zdecentralizowana produkcja. Taka sytuacja oznacza wzrost bezpieczeństwa energetycznego obywateli oraz uniezależnienie się od wielkich producentów energii i jej przesyłania na duże odległości (zob. Campos, Marín-González i in., 2019, 6781). Prosumenci stanowią wyzwanie 
dla dotychczasowych graczy rynku energii, ponieważ tego rodzaju produkcja oznacza konieczność dostosowania tradycyjnego modelu biznesowego do nowych okoliczności (zob. wykres 6).

\section{Wykres 6. Struktura własności instalacji OZE (przykład: Niemcy)}

Podzial wlasności instalacji do produkcji prądu z OZE w Niemczech w 2012 roku

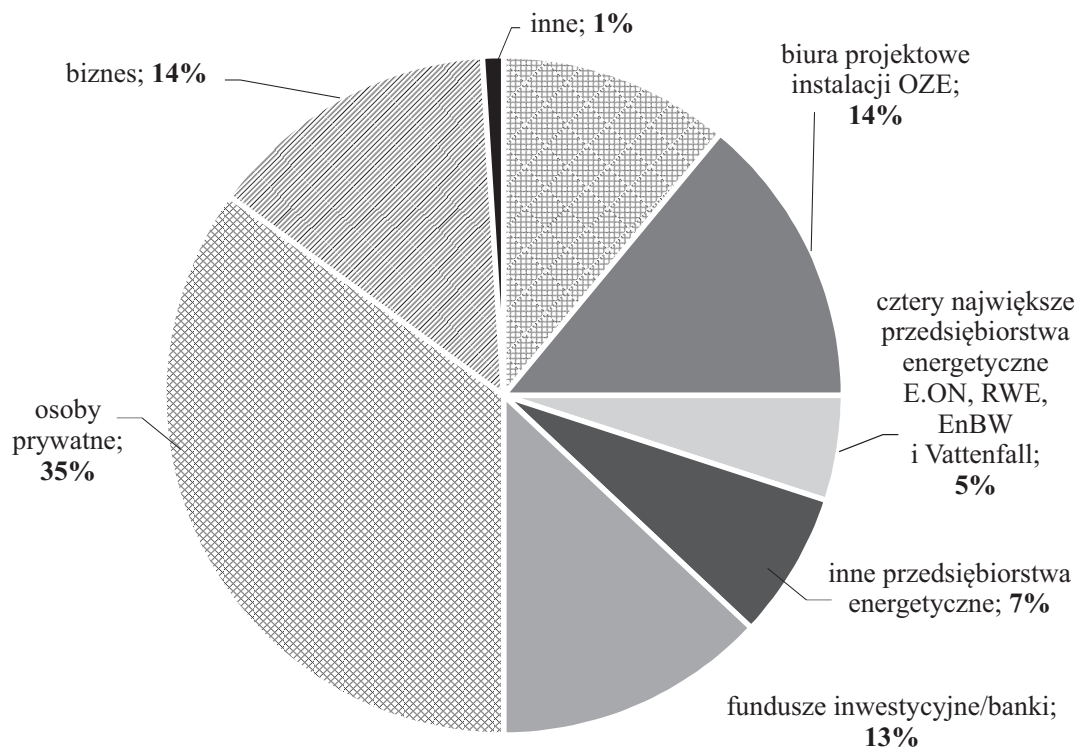

Źródło: Na podstawie R. Bajczuk, Odnawialne źródla energii w Niemczech. Obecny stan rozwoju, grupy interesu, wyzwania. Raport OSW, Warszawa, czerwiec 2014, s. 38.

- użytkownik - czyli osoba, która korzysta z energii w swoim gospodarstwie domowym. Ma świadomość kosztów, które jej użycie generuje dla budżetu. Użytkownik stara się kontrolować ilość zużywanej energii, stosuje technologie zwiększające efektywność jej wykorzystania (np. urządzenia o wysokiej skali efektywności energetycznej - A++), korzysta ze zróżnicowanych planów taryfowych, umożliwiających konsumpcję energii po niższych cenach w zależności od pory dnia. Użytkownik oczekuje również energii wysokiej jakości oraz odpowiedniej efektywności w działaniu systemów przesyłowych, aby nie pojawiały się przerwy w dostawach (por. Labanca, Bertoldi, 2018, s. 494-502). 
Reasumując powyższe, społeczeństwo - nolens volens - jest włączone w mechanizmy polityki energetycznej. Wzrost świadomości obywateli oraz większe zaangażowanie powodują, iż zarówno rządzący, jak również przedsiębiorstwa muszą brać to pod uwagę. Dla rządzących taka tendencja oznacza konieczność uwzględniania nie tylko uwarunkowań politycznych i gospodarczych, ale również społecznych przy planowaniu działań w sektorze energetycznym. Dla przedsiębiorstw natomiast - jest to kwestia „być” lub „nie być” w odniesieniu do nowych inwestycji, czy projektów. Bez dialogu ze społeczeństwem (na poziomie regionalnym/ lokalnym) realizacja zamierzonych projektów może okazać się tyleż trudna, co wręcz niemożliwa (Rychlicki, Kosowski i in., 2016, s. 133-146).

\section{Problemy związane ze spolecznym oddziaływaniem na politykę energetyczną}

Dotychczasowa analiza wskazuje, iż wpływ społeczny jest nie tylko możliwy, ale wręcz konieczny dla zapewnienia efektywnej realizacji polityki energetycznej, w szczególności w perspektywie osiągania jej celów.

Stosując podejście dialektyczne, tę optymistyczną wizję można skonfrontować z nieco bardziej pesymistyczną, w której udział społeczny można byłoby uznać za zbędny lub wręcz niepożądany. Rysuje się - w tym kontekście - kilka ważnych kwestii.

Po pierwsze, problem technokracji - polityka energetyczna jest polityką gospodarczą. Jej kształtowanie wymaga specjalistycznej wiedzy osób posiadających niezbędne kwalifikacje, jak również orientację w zakresie kształtowania zmiany gospodarczej, konstruowania bilansu energetycznego, czy wyboru takich źródeł energii, które w przyszłości okażą się perspektywiczne (np. gaz łupkowy). Takie grupy ludzi (inżynierów, doradców, specjalistów) zrzeszone na przykład w: think-tankach, grupach roboczych, czy różnego rodzaju komitetach, albo działające pod szyldem danej branży (np. górnictwo węgla kamiennego) oddziaływają na rządzących w taki sposób, aby przekonać ich, że podejmowanie decyzji w oparciu o opinie środowisk eksperckich jest najlepszym możliwym wyborem. Kształtowanie polityki energetycznej przez ekspertów ma zapewnić danej ekipie sukces wyborczy, a państwu - bezpieczeństwo energetyczne. Myśląc w kategoriach „paradygmatu technokratycznego”, eksperci lepiej wiedzą jak zmienić sektor energetyczny, niż obywatele, którzy są jedynie biernymi końcowymi odbiorcami energii. W tej wizji 
obywatel nie jest podmiotem, lecz jedynie klientem, opłacającym rachunki. Najważniejsze jest, aby regulował je na czas.

Przechodząc do przykładów obrazujących taki styl działania, można wskazać wdrażanie technologii jądrowej we Francji. Eksperci - absolwenci elitarnych szkół paryskich (w szczególności: École Politechnique, École Nationale Supérieure des Mines de Paris) wskazali rządzącym drogę ku energii przyszłości, czyli energii jądrowej (Schneider, 2010, s. 195-196). Zapewniono państwu odpowiedni poziom bezpieczeństwa energetycznego, a francuska technologia nuklearna stała się wizytówką eksportową kraju na wiele lat. Nie jest to jednak historia sukcesu. Francja od kilku lat zmierza w kierunku modyfikacji swojego bilansu energetycznego i wzmocnienia udziału odnawialnych źródeł energii, aby zminimalizować uzależnienie gospodarki od energetyki jądrowej i dostosować się do standardów polityki energetyczno-klimatycznej UE.

Po drugie, problem elity wpływu - stanowi on rozwinięcie powyższej wizji oddziaływania technokratów na kształt polityki energetycznej. Jeśli przyjąć - jako podstawę analizy - teorię elit C. W. Millsa, sfery: polityczna, ekonomiczna i wojskowa przenikają się wzajemnie (zob. Mills, 1961). Ludzie elity podejmują decyzje wywołujące skutki w skali ogólnokrajowej.

W przypadku polityki energetycznej kluczowe wydaje się zwłaszcza podjęcie analizy dwóch płaszczyzn: politycznej i gospodarczej (korporacje - przedsiębiorstwa energetyczne). Elity polityczne mają żywotny interes przede wszystkim w tym, aby uwzględniać oczekiwania elit gospodarczych, a nie głos społeczności. Elity gospodarcze bowiem dostarczają władzy politycznej nie tylko wiedzy eksperckiej, ale również dysponują zasobami finansowymi, które są niezbędne dla realizacji programów politycznych promowanych przez rządzących.

Społeczeństwo - w takiej wizji - nie jest graczem o kluczowym znaczeniu. Elity projektują zmianę gospodarczą w taki sposób, aby zabezpieczyć swoje najważniejsze interesy zarówno w sferze polityki, jak i ekonomii (por. Czyżewski, Franczak i in., 2014).

Za przykład takiej strategii współdziałania może posłużyć problematyka wydobycia gazu lupkowego w Polsce. Nie wnikając w meandry krótkiej, acz burzliwej historii tej problematyki, można wskazać, iż kompleksowe badania geologiczne $\mathrm{w}$ tym zakresie, wykonane $\mathrm{w}$ pierwszej dekadzie XXI wieku, dawały znaczne nadzieje na przemysłowe wydobycie tego surowca w Polsce. Oznaczałoby to nie tylko uniezależnienie się od dostaw rosyjskiego gazu, ale również szansę na eksport polskiego 
gazu łupkowego na rynki zagraniczne. Byłby to przełom w sektorze energetycznym, który można byłoby porównać z Kopernikańskim w astronomii. Władze polityczne i krajowy biznes energetyczny szybko znalazły porozumienie w sprawie realizacji pierwszych wierceń.

Zapowiedzi okazały się jednak bardziej optymistyczne, niż rzeczywistość i w rezultacie Polska nie stała się łupkowym potentatem (Gawlik, 2013, s. 38-40; Siemek, Nagy, 2012, s. 37-59). Krótka historia polskiego gazu łupkowego pokazuje, iż krajowe elity polityczne i gospodarcze szybko osiągnęły porozumienie w zakresie rozwijania technologii, która w Europie nie znajduje społecznego poparcia. Z tego względu nie jest de facto wykorzystywana na skalę przemysłową na Starym Kontynencie (w USA - gaz łupkowy jest wprawdzie pozyskiwany, ale budzi to liczne protesty społeczności oraz organizacji ekologicznych).

Konkludując, interes społeczny wydaje się drugorzędny, kiedy w grę wchodzą interesy elit politycznych i gospodarczych. Poszukiwanie w tej sytuacji poparcia społecznego mogłoby zakończyć się niepowodzeniem, czyli pokrzyżowałoby plany elit.

Po trzecie, problem partykularyzmów społecznych - można uznać, że zapewnienie skutecznego oddziaływania społecznego (rozumianego jako ogół społeczeństwa) na kształt polityki energetycznej i sektora energetycznego jest szlachetną ideą, ale bez możliwości wdrożenia jej w praktyce, z uwagi na potencjalnie (i realnie) sprzeczne wektory potrzeb i oczekiwań. Jeśli przyjąć, że polityka energetyczna i sektor energetyczny mają służyć: państwu, interesowi publicznemu, obywatelom czy odpowiadać światowym tendencjom - tzw. mega trendom, to zawsze istnieje ryzyko konfrontacji tych wartości z partykularnymi interesami danej społeczności, czy grupy zawodowej, związanej z daną branżą. W tej sytuacji realizacja ogólnych celów, zgodnych z szeroko pojętym interesem publicznym wydaje się niemożliwa.

Przykładem ilustrującym powyższe problemy jest syndrom NIMBY (zob. Dmochowska-Dudek, 2013). Jeśli planowana inwestycja jest ważna dla całego kraju i ogółu społeczeństwa, ale nie odpowiada lokalnej społeczności, wówczas ta może zablokować losy projektu, który ma znaczenie dla wszystkich. Interes małej grupy weźmie górę nad interesem ogółu.

Podobna sytuacja pojawia się w przypadku wyzwań restrukturyzacyjnych. Górnictwo węgla kamiennego w Polsce jest sektorem wymagającym poważnych przekształceń prywatyzacyjnych. Jednak potencjalne działania rządu w tym zakresie spowodują ograniczenie zatrudnienia w branży i poważne problemy związane z bezrobociem. Taki drastyczny program 
restrukturyzacji służyłby naprawie nierentownej branży, a z punktu widzenia ogółu społeczeństwa - pozwoliłby ograniczyć obecność państwa w sektorze wymagającym wparcia ze środków publicznych. Jednak z perspektywy mieszkańców regionów górniczych oznaczałoby to zapewne: wzrost bezrobocia, trudności na lokalnym rynku pracy, nasilenie patologii społecznych itd. Dlatego kolejne rządy (bez względu na poglądy polityczne) odkładają rozwiązanie tej kwestii. W ten sposób partykularne interesy jednej grupy (w tym przypadku związanej z przemysłem wydobywczym) rzutują na sytuację całego państwa i społeczeństwa.

Podobnych przykładów można byłoby dostarczyć znacznie więcej, ale przekracza to możliwości niniejszego artykułu. Problem partykularyzmów ma szersze znaczenie, niż tylko w odniesieniu do gospodarki jednego państwa. Podobne zjawiska można zauważyć w Unii Europejskiej, gdzie interesy państw i społeczeństw stawiających na ochronę środowiska i produkcję energii ze źródeł odnawialnych (np. Niemcy, Dania, Szwecja) kontrastują z wizją krajów, gdzie nadal dominują paliwa kopalne w bilansie energetycznym (np. Polska, Rumunia). Rodzi to poważne problemy, które rzutują na zjawisko europejskiej solidarności energetycznej (zob. Tomaszewski, 2018, s. 5-18).

\section{Podsumowanie}

Zmiany w obszarze nowych technologii, spadek cen urządzeń do produkcji energii ze źródeł odnawialnych, jak również "moda na ekologię” powodują wzrost świadomości i zainteresowania obywateli problematyką wytwarzania, konsumpcji i oszczędzania energii. Taka sytuacja ma - jak się wydaje - bezpośredni wpływ na kształtowanie polityki energetycznej (Komisja Europejska, 2016). Przestaje być ona jedynie domeną rządu, organizacji międzynarodowych czy przedsiębiorstw energetycznych. W tym zestawieniu podmiotów sprawczych - interesariuszy należy bezwzględnie brać pod uwagę społeczeństwo z jego potrzebami i oczekiwaniami (Ribeiro, Ferreira, Araújo, 2011, s. 4361-4364).

Jak wskazano w powyższym tekście, państwa o reżimie demokratycznym i gospodarce rynkowej powinny tak dostosować istniejące normy prawne, aby na każdym etapie tworzenia polityki energetycznej (zwłaszcza w odniesieniu do jej planowania oraz implementacji) obywatele mieli wpływ na kształtowanie swojego otoczenia. Jest to conditio sine qua non efektywnego wdrażania zmiany gospodarczej i budowania nowoczesne- 
go społeczeństwa, gdzie obywatele czują się współodpowiedzialni za rządzenie państwem nie tylko na etapie wyborów parlamentarnych, ale również w odniesieniu do spraw mających wpływ na codzienne funkcjonowanie ich gospodarstw domowych.

Dla przedsiębiorstw sektora energetycznego, uwzględnianie czynnika społecznego oznacza: konieczność stosowania reguł CSR, dialog ze społecznościami lokalnymi, potrzebę dokonywania pewnych koncesji, czy zmian w procesach inwestycyjnych w relacji do oczekiwań społecznych, manifestowanych poprzez mniej lub bardziej spontaniczne działania.

Tym samym, założenie badawcze w postaci hipotezy postawionej we wprowadzeniu do niniejszego artykułu można uznać za adekwatne i uzasadnione.

Takie wnioski nasuwają się na podstawie analizy rzeczywistości gospodarczo-społecznej oraz po uwzględnieniu obecnego tempa rozwoju technologicznego. Już dzisiaj odnawialne źródła energii stają się oczywistym sposobem pozyskiwania ekologicznej, taniej energii. Technologie magazynowania energii (tzw. power wall) są coraz bardziej wydajne i coraz tańsze w zakupie i serwisowaniu. Produkcja energii na potrzeby indywidualne czy zbiorowe - społeczności lokalnej jest w wielu krajach (np. Niemcy) opłacalna finansowo i korzystna z punktu widzenia poprawy bezpieczeństwa energetycznego (np. niwelowanie problemu tzw. wysp energetycznych) (Knopf, Schmid, Pechan, 2016, s. 263-275). Ekologiczna energia może również stać się podstawą nowoczesnego transportu opartego na elektromobilności. Przyszłość sektora energetycznego jest zatem w rękach społeczeństwa.

Nie należy jednak zapominać, iż udział czynnika społecznego powinien być odpowiednio zabezpieczony w aktach prawnych, które będą gwarantowały obywatelom adekwatny wpływ na politykę energetyczną. Bez uwzględnienia tego postulatu istnieje ryzyko nadmiernej technokratyzacji sektora, czy zdominowania decyzji w tym zakresie przez wąskie elity polityczno-gospodarcze, albo inne dobrze zorganizowane grupy wpływu. Polityka energetyczna będzie wówczas domeną realizacji ich partykularnych interesów.

\section{Bibliografia}

Bajczuk R. (2014), Odnawialne źródta energii w Niemczech. Obecny stan rozwoju, grupy interesu, wyzwania, „Raport Ośrodka Studiów Wschodnich”, Warszawa. 
Bezpieczeństwo energetyczne $w$ programach partii politycznych (2015), Ośrodek Analiz Politologicznych Uniwersytetu Warszawskiego - debata z dn. 16.10.2015, http://bepk.oapuw.pl/bezpieczenstwo-energetyczne-w-programach-partii-politycznych/, 3.03.2019.

Bosch S., Schwarz L. (2019), The energy transition from plant operators' perspective - a behaviorist approach, „Sustainability”, vol. 11, 1621.

Campos I., Marín-González E., Luz G., Barroso J., Oliveira N. (2019), Renewable Energy Prosumers in Mediterranean Viticulture Social-Ecological Systems, „Sustainability”, vol. 11, 6781.

Chmaj M., Żmigrodzki M. (1996), Wprowadzenie do teorii polityki, UMCS, Lublin.

Czyżewski M., Franczak K., Nowicka M., Stachowiak J. (2014), Dyskurs elit symbolicznych. Próba diagnozy, Wydawnictwo Akademickie Sedno, Warszawa.

Frączek P. (2011), Przeciwdziałanie konfliktom lokalizacyjnym $w$ sektorze energii, „Polityka Energetyczna - Energy Policy Journal”, nr 14 (2), s. 65-78.

Nikhil D. (2018), The Fukushima Disaster and the Framing of Nuclear Energy in India, „Perspectives on Global Development and Technology”, no. 17, s. 473-495.

Deloitte (2016), Polska energetyka na fali megatrendów, Deloitte i Forum Analiz Energetycznych, Warszawa.

Dmochowska-Dudek K. (2013), Syndrom NIMBY w przestrzeni wielkomiejskiej. Przykład Łodzi, Wydawnictwo Uniwersytetu Łódzkiego, Łódź.

Florini A., Sovacool B. (2009), Who governs energy? The challenges facing global energy governance, „Energy Policy”, no. 37 (12), s. 5239-5248.

Gawlik L. (2013), Gaz ziemny z łupków w Polsce-raport, Polski Komitet Światowej Rady Energetycznej, Warszawa.

Gołaszewska-Kaczan U. (2009), Zaangażowanie społeczne przedsiębiorstwa, Wydawnictwo Uniwersytetu w Białymstoku, Białystok.

Gryz J. (2018), Bezpieczeństwo energetyczne - związi między nauka, polityka a rzeczywistościa, w: Bezpieczeństwo energetyczne. Koncepcje, wyzwania interesy, red. J. Gryz, A. Podraza, M. Ruszel,Wydawnictwo Naukowe PWN, Warszawa, s. 21-45.

Gwiazda M., Ruszkowski P. (red.) (2016), Polacy o źródłach energii, polityce energetycznej i ochronie środowiska, CBOS „Opinie i diagnozy”, nr 34, Warszawa.

Hausner J. (2007), Ekonomia społeczna jako sektor gospodarki, „Kwartalnik Ekonomia Społeczna", nr 01/(1), s. 9-14.

Jagusiak B. (2015), Wplyw bezpieczeństwa energetycznego na bezpieczeństwo socjalne Polaków w perspektywie zachodzacych procesów integracji i globalizacji, w: Energetyka w czasach politycznej niestabilności, red. P. Kwiatkiewicz, R. Szczerbowski, FNCE, Poznań, s. 121-136.

Knopf B., Schmid E., Pechan A. (2016), Putting an energy system transformation into practice: The case of the German Energiewende, „Energy Research \& Social Science", no. 11, s. 263-275. 
Knox-Hayes J., Brown M. A., Sovacool B. K., Wang Y. (2013), Understanding attitudes toward energy security: Results of a cross-national survey, „Global Environmental Change", vol. 23, issue 3, s. 609-622.

Komisja Europejska (2001), Green paper: Promoting a European framework for corporate social responsibility, COM 366.

Komisja Europejska (2010), Energia 2020. Strategia na rzecz konkurencyjnego, zrównoważonego i bezpiecznego sektora energetycznego, COM 639.

Komisja Europejska (2015), Strategia ramowa na rzecz stabilnej unii energetycznej opartej na przyszłościowej polityce $w$ dziedzinie klimatu, COM 80.

Komisja Europejska (2016), Czysta energia dla wszystkich Europejczyków, COM 860.

Komisja Europejska (2017), Biała księga Komisji w sprawie przyszłości Europy. Refleksje i scenariusze dotyczace przyszłości UE-27 do 2025 r., COM 2025.

Konwencja z Aarhus (1998), Konwencja o dostepie do informacji, udziale społeczeństwa $w$ podejmowaniu decyzji oraz dostępie do sprawiedliwości $w$ sprawach dotyczacych środowiska (sporządzona w Aarhus dnia 25 czerwca 1998 r.), Dz. U. 2003, Nr 78, poz. 706.

Labanca N., Bertoldi P. (2018), Beyond energy efficiency and individual behaviours: policy insights from social practice theories, „Energy Policy”, vol. 115, s. 494-502.

Łucki Z., Misiak A. (2010), Energetyka a społeczeństwo. Aspekty socjologiczne, Wydawnictwo Naukowe PWN, Warszawa.

Łucki Z. (2010), Instrumenty polityki energetycznej, „Polityka Energetyczna - Energy Policy Journal", nr 12 (1), s. 5-20.

Mielczarski W. (2009), Atomowe za i przeciw (cz. 2), „INFOS - Biuro Analiz Sejmowych", nr 21 (68), s. 1-4.

Mills Ch. W. (1961), Elita władzy, Książka i Wiedza, Warszawa.

Ministerstwo Energii (2017), Koncepcja funkcjonowania klastrów energii w Polsce, oprac. KAPE, Wise Europa, Atmoterm S.A., Krajowy Instytut Energetyki Rozproszonej, Warszawa, http://www.me.gov.pl/Energetyka/Koncepcja+klastrow/Zestawienie+opinii+nt+ekspertyzy+Koncepcja+funkcjonowania+klast row + energii $+\mathrm{w}+$ Polsce, 12.01.2019.

Młynarski T. (2018), Rola i perspektywy energetyki jądrowej w zapewnieniu bezpieczeństwa energetyczno-klimatycznego Unii Europejskiej, w: Bezpieczeństwo energetyczne. Koncepcje, wyzwania interesy, red. J. Gryz, A. Podraza, M. Ruszel, s. 81-96, Wydawnictwo Naukowe PWN, Warszawa.

Mrozowska S. (2016), Polityka energetyczna Unii Europejskiej. Między strategia, lobbingiem a partycypacją, Libron, Kraków.

Pachocki K. (red.) (2006), Czarnobyl - 20 lat później: skażenie środowiska i żywności, skutki zdrowotne, energetyka jądrowa w Polsce - za i przeciw, Towarzystwo Badań Radiacyjnych im. Marii Skłodowskiej-Curie, Zakopane. 
Ribeiro F., Ferreira P., Araújo M. (2011), The inclusion of social aspects in power planning, „Renewable and Sustainable Energy Reviews”, no. 15 (9), s. 4361-4369.

Rychlicki S., Kosowski P., Wartak J., Solecki M. (2016), Ocena społecznej akceptacji przemystu naftowego w Polsce, „Polityka Energetyczna - Energy Policy Journal", nr 19 (3), s. 133-146.

Schneider M. (2008), Nuclear Power in France. Beyond the Myth, Report commissioned by the Greens-EFA Group in the European Parliament, Brussels, https://www.greens-efa.eu/en/cms/topics/dokbin/258/258614, 11.02.2019.

Schneider M. (2010), Nuclear Power Made in France: A Model?, w: Nuclear Power's Global Expansion: Weighing Its Costs and Risks, red. H. Sokolski, Strategic Studies Institute, Carlisle, s. 189-278.

Sekuła P. (2009), Kultura polityczna a konsolidacja demokracji, AFM, Kraków.

Standardowy Eurobarometr (2014), Opinia publiczna w Unii Europejskiej - raport krajowy: Polska, nr 82, Eurostat, Bruksela.

Standardowy Eurobarometr (2017), Poglądy Europejczyków na temat priorytetów Unii Europejskiej, Eurostat, Bruksela.

Stankiewicz P., Stasik A., Suchomska J. (2015), Od informowania do współdecydowania i z powrotem. Prototypowanie technologicznej demokracji, „Studia Socjologiczne", nr 3 (218), s. 65-101.

Stankiewicz P. (2016), Od Czarnobyla do Fukushimy. O społecznej konstrukcji bezpieczeństwa energetyki jądrowej, „Transformacje”, nr 1-2 (88-89), s. 213-238.

Strupczewski A. (2009), Atomowe za i przeciw (cz. 1), „INFOS - Biuro Analiz Sejmowych", nr 20 (67), s. 1-4.

Szczerbowski B., Ceran B. (2017), Polityka energetyczna Polski w aspekcie wyzwań XXI wieku, „Polityka Energetyczna - Energy Policy Journal”, nr 20 (3), s. 1728.

Szot-Gabryś T. (2013), Koncepcja rachunku kosztów i korzyści w rachunkowości odpowiedzialności społecznej przedsiębiorstwa, Difin S.A., Warszawa.

Szustek A. (2009), Polski sektor społeczny, Aspra-JR, Warszawa.

Tomaszewski K. (2017), Komunikowanie reform w polityce energetycznej Unii Europejskiej na przykładzie zielonych $i$ biatych ksiag, Kwartalnik Naukowy „e-Politikon”, nr 21, s. 78-101.

Tomaszewski K. (2018), Energy solidarity in the European Union in the context of the particular interests of the Member States, „Polityka Energetyczna - Energy Policy Journal", nr 21(2), s. 5-18.

Wagner A. (2016), Medialny dyskurs energetyczny jako przedmiot refleksji socjologicznej - kontekst teoretyczny i metodologiczny, w: Widoczne i niewidoczne: Atom, tupki, wiatr $w$ dyskursach medialnych wokół energetyki, red. A. Wagner, Wydawnictwo Uniwersytetu Jagiellońskiego, Kraków, s. 11-32.

Von Hirschhausen Ch. (2014), The German “Energiewende”- an Introduction, „Economics of Energy \& Environmental Policy”, no. (3) 2, s. 1-12. 
The role of the human factor in shaping the energy policy of contemporary states

\begin{abstract}
Summary
Energy policy is included in the category of economic policies. However, it has a very strong impact on the functioning of the whole of society. The purpose of the article is to analyze how energy policy is (or can be) shaped under the influence of the human factor, and how important the human factor is in the context of its planning, implementation and evaluation. The subject of the analysis are, first and foremost, the states (or organizations of states, such as the European Union) with a democratic regime and a free market economy. These two features provide the most favorable conditions for society to effectively influence the shape and functioning of the energy sector. The article's aim is to identify potential (real) possibilities of the human factor participating in energy policy through a processual analysis of this policy.
\end{abstract}

Key words: economy, energy, energy policy, public opinion, civil society 
